Hans Erik Avlund Frandsen, Lone Bentzen, Lisbeth Pedersen, Nielsine Poulsen, Gurli Rasmussen, Vibeke Thorshøj, Margit Thorsvang

\title{
Arbejderbevidsthed og arbejderkultur i mellemkrigstiden
}

Ib Bondebjerg og Olav Harsløf (red.): Arbejderkullur 1924-48. 555 s., 150 kr. Medusa 1979

lb Bondebjerg: Proletarisk offentlighed 2.386 s., 89,50 kr. Medusa 1980.

1.

I Proletarisk offentlighed 2 citerer Bondebjerg med tilslutning Mich. Vesters definition af arbejderkultur. Den er »ikke proletarisk kunst eller rådhuse eller en særlig sprogbrug, den er snarere en grundlæggende kollektiv ide og de institutioner, holdninger, bevidsthedsformer og intentioner, som følger heraf."

Arbejderkulturen adskiller sig altså kvalitativt fra den borgerlige kultur i kraft af kollektiviteten og solidariteten (i modsætning til den borgerlige individualisme). Osse kvantitativt er der tale om en overskridelse af det snævre borgerlige kulturbegreb, idet kultur her forstås som holdninger til og organisering af hele livssammenhængen, altså osse den del af den, der har med produktion, økonomi og levevilkår at gøre.

I antologien ytrer det sig i et bredt tekstudvalg, der belyser bl.a. arbejdsvilkår, strejker, arbejdsløshed, fagbevægelse, præventions-, abort- og andre seksualproblemer, sport og lejrliv, boligforhold, forbrug, uddannelse og opdragelse, kulturpolitik, arbejderkunst og socialistisk æstetik.

De forskellige artikler er suppleret med et billedmateriale, der er godt nok til at man xrgrer sig over, at ikke endnu flere billeder er kommet med. Osse fordi billeder ofte viser forhold, som ikke er tilgængelige via andre kilder.

De centrale kapitler i Proletarisk offentlighed 2 består af en analyse af Socialdemokratiets og DKPs kulturpolitik i mellemkrigstiden og en (dygtig og inspirerende) fortolkning af 3 arbej- 
derforfattere: de to socialdemokrater Nils Nilsson og Peder Hansen og den ikke alt for partitro kommunist Harald Herdal.

\section{2.}

Begge bøger er forsynet med nogle oversigtskapitler, hvor de vigtigste temaer sættes ind $i$ en historisk og samfundsmæssig ramme. Her er de i traditionel forstand mere »kulturelle« emner godt og rimeligt pædagogisk belyst, men de politisk-økonomiske afsnit er for svage, selv om man vitterligt får mange relevante og korrekte oplysninger. Bondebjerg og Harsløf løber imidlertid lidt for ofte med en halv vind og bruger tit meget generelle formuleringer. Det medfører, at det både er svært at få fat $\mathrm{i}$, hvad der helt konkret menes, og at beskrivelsen ofte lige så godt (undertiden bedre) kunne bruges til en fremstilling af udviklingstendensen i 50erne og 60erne. Det gælder f.ex. spørgsmålet om »funktionstømningen« af familien og om forandringerne i erhvervsstrukturen.

Om det sidste hedder det således $\mathrm{i}$ antologiens indledning, at der i perioden fandt en udvikling sted »frem mod den storindustrielle produktionsform«, noget der oven i købet skulle have haft »stor betydning for arbejderklassens kamp-, kooperationsog bevidsthedsformer ( 21 ).

Naturligvis er udviklingen i erhvervsstrukturen af helt afgørende betydning for den særlige danske udgave af den reformistiske bevidsthed. Det der betyder noget er jo imidlertid ikke kapitalismens generelle udviklingstendens, men de konkrete forhold, der er fremherskende i den bestemte historiske periode, man beskæftiger sig med. Og her forholder det sig faktisk sådan, at det danske erhvervsliv stadigvæk i eminent grad var domineret af $s m a ̊$ virksomheder. I 1925 havde $92,1 \%$ af virksomhederne indenfor håndværk og industri mellem 0 og 5 ansatte. I 1948 gjaldt det $87,4 \%$ af virksomhederne. De store virksomheder med over 100 ansatte udgjorde kun $0,3 \%$ i 1925 og $0,5 \%$ i 1948.

Ser man på hvor mange der var ansat på disse få store virksomheder, så drejede det sig om 30,4\% af arbejderne i 1925 og $31,7 \%$ i 1948 . I perioden forud for den antologien dækker, kun- 
ne man derimod med større ret tale om en betydningsfuld udvikling i retning af stordrift. Mens kun knap hver femte arbejder var ansat på en af de store virksomheder i 1897, så var det i 1925 knap hver tredje (3 ud af 10).

\section{3.}

Begge bøger er kritiske overfor dén socialdemokratiske og - i langt mindre målestok - kommunistiske form for arbejderkultur, der har varet dominerende i den danske arbejderklasse. Kritikken - som specielt fremføres i Bondebjergs bog - henter sin målestok fra Negt og Kluges begreb om en »proletarisk offentlighed«. Det er et begreb som ud fra en marxistisk analyse af de objektive klassemodsætninger peger på nødvendigheden af at udvikle organisations-, samværs- og kampformer som

1) udspringer af og forholder sig til hele arbejderklassens erfaringsverden og ikke kun til den økonomiske og arbejdsmæssige side af den

2) knytter forbindelsen mellem arbejdernes objektive situation som undertrykt klasse og de faktisk eksisterende subjektive behov, fortolkninger og erfaringer, der oftest ikke er sammenfattet $i$ en egentlig klassebevidsthed

3) bygger på princippet om at arbejderklassens frigørelse ikke kan ske pr. stedfortræder, men kun gennem de mange enkelte arbejderes egen kollektive erfaringsbearbejdelse og kamp.

Det siger sig selv, at den socialdemokratiske, hierarkiskrepræsentative og klassesamarbejdende arbejderbevægelse ikke har ret meget at gøre med en sådan proletarisk offentlighed. $\mathrm{Og}$ DKP kritiseres for netop at forsømme den del af arbejderklassens liv, der ikke drejer sig om arbejde og politik. En ensidighed som betød at hele det ubearbejdede område lå åbent for borgerlig udnyttelse.

Ingen af bøgerne tager imidlertid fat på de kimformer til udvikling af en proletarisk offentlighed, som man givetvis ville kunne finde, hvis man udforskede periodens mange strejker, de forskellige oppositionsbevægelser, lokale organiseringer af forskellig art og fagligt og politisk arbejde længere ned i hierarkiet end det topniveau, der har afgivet størstedelen af materialet til 
disse to bøger.

Denne prioritering korresponderer dårligt med den titel Bondebjerg har givet sin bog, men ellers er det jo ikke forkert, at den første betingelse for at forstå hvilke muligheder, der var/er for at udvikle en proletarisk offentlighed, er at man forstår hvorfor arbejderklassen i så udpræget grad sluttede op om Socialdemokratiet. Eller med andre ord: den første opgave bliver at få kastet lys over den historisk eksisterende arbejderbevidsthed og arbejderkultur.

Gør de to bøger så det? Kun delvist:

4.

Det anvendte kildemateriale er for snævert og i visse tilfælde uegnet til formålet. Groft sagt făr man kun noget at vide om toppen af isbjerget, en begrænsning der naturligvis hænger snævert sammen med at hele dette område mildest talt ikke hidtil har haft forskernes bevågenhed. Men det hænger osse sammen med, at Bondebjerg og Harsløf har deres force indenfor den del af feltet, der handler om litteratur, kulturdebat og kulturpolitik. Her har de fast grund under fødderne. Det har de ikke, der hvor det drejer sig om økonomi, politik, arbejdskampe og levevilkår, hvad der viser sig i en vis skævhed både i tekstudvalget og i vurderingerne.

Mht. tekstudvalget er det problematisk, at kulturdebatten og kulturpolitikken har faet uforholdsmæssig megen plads. Det betyder positivt, at læserne her er dækket virkelig godt ind. Bagsiden af medaljen er, at andre temaer har fået en mere stedmoderlig behandling. F.ex. er der kun brugt halvt så mange sider på afsnittet om arbejdsvilkår, fagbevægelse og arbejdskampe. Her har Bondebjerg og Harsløf ikke taget konsekvensen af den brede kulturdefinition, men overhales venstre om af den senere socialdemokratiske undervisningsminister Hartvig Frisch, som i 1931 fremhævede, at fagforeningsbogen var den vigtigste bog for arbejderkulturen.

Det kniber således med at få overblik over forløbet i arbejderklassens forskellige former for kamp og organisering. Der mangler noget om det store flertal, som arbejder på små virk- 
somheder. Man får osse for lidt at vide om, hvordan de forskellige strejker var organiseret, hvilke erfaringer man gjorde, og hvordan forholdet var mellem de strejkende og deres familier.

I det hele taget er arbejderkvindernes situation og betydning underbelyst. Det er mands arbejdspladsoplevelser, mands fagbevægelse og mands arbejdsløshed, der beskrives. Det vigtigste er dog nok, at der gøres så lidt ud af kvindernes arbejde med hjem og børn. Bondebjerg påpeger med rette det begrænsede $\mathrm{i}$ Nils Nilssons synsvinkel, når han $i$ sine romaner helt har fortrængt »problemet om kvindernes erhvervsmæssige inddragelse og faglige og politiske organisering og udelukkende beskriver arbejderkvindernes bevidsthed "som rettet ind mod at hæve hjemmets standard og opdrage børnene« (93).

Det er-imidlertid vigtigt at holde fast, at denne kritik henter sin begrundelse fra en ideel eller teoretisk socialistisk opfattelse. Sandsynligvis var Nilssons beskrivelse $\mathrm{i}$ hovedsagen $\mathrm{i}$ overensstemmelse med langt de fleste arbejderkvinder, som ud fra det materiale, vi kender til, enten ikke havde erhvervsarbejde eller opfattede dette som et nødvendigt onde for bedst muligt at kunne opretholde den familie som deres følelser, engagement og behov var bundet til i langt højere grad end til arbejdet uden for hjemmet. Vi mener, at man her har en vigtig indfaldsvinkel til en bedre forståelse af arbejderbevidstheden, og at dette område spillede en langt større rolle i virkelighedens arbejderklasse end f.ex. de overdådigt repræsenterede diskussioner om socialistisk æstetik.

Det centrale i vores kritik er netop, at det er tvivlsomt, om det egentlig er arbejderklassens kultur og bevidsthed, der beskrives i tekstudvalget. Langt de fleste tekster er hentet fra diverse venstrefløjstidsskrifter (ofte af kulturradikal observans) og fra centralt placerede folk i Socialdemokratiet og DKP. De er som regel skrevet af mere eller mindre professionelle - ofte akademiske - skribenter eller politikere og kun i enkelte tilfælde af egentlige arbejdere. Vi skal gerne indrømme, at man her står over for store problemer med at finde et mere egnet materiale, men mener dog, at der med fordel kunne være trukket på nogle af de mange arbejdererindringer, der findes på Københavns Stadsarkiv. 
5.

I Proletarisk offentlighed 2 har Ib Bondebjerg valgt en anden indfaldsvinkel, idet han via en analyse af arbejderlitteraturen og kulturpolitikken vil nå frem til »en forståelse af arbejderklassens bevidsthedsformer og erfaringer« (14). Det er ikke noget uproblematisk projekt, men resultatet viser for os at se, at man i hvert fald i de litterære skildringer har en vigtig kilde, som hidtil er udnyttet alt for lidt.

De 3 forfattere Bondebjerg analyserer, beskriver og fortolker arbejderklassens liv og bevidsthed på 3 forskellige måder. Hos Nils Nilsson skildres overgangen fra en småborgerlig til en industriel produktionsmåde som en proces, der i det enkelte individ betyder en udvikling fra individualisme til klassesolidaritet. Det er selve arbejdet og den kollektive arbejdsproces, der har denne positive opdragende virkning.

Nilsson viser imidlertid osse, hvordan netop respekten for arbejdet kan forene arbejder og arbejdsgiver i et frugtbart samarbejde, og han antyder, at denne (socialdemokratiske) kombination fører frem mod en ikke nærmere tids- eller indholdsbestemt frigørelse for arbejderklassen.

Dette udviklingsforløb er beskrevet som en naturlig vækstproces og arbejdere, der falder uden for mønstret (ved f.ex. at blive syndikalister) beskrives derfor logisk nok som unaturlige og syge.

Der er altså således på én gang tale om en skildring af en socialhistorisk realitet og om en ideologisk fortrængning af kapitalismens fundamentale undertrykkelsesmekanismer.

Hos Peder Hansen er skyggesiderne ved arbejdslivet trukket meget skarpere op. Men vel at mærke ikke med noget antikapitalistisk perspektiv. Det positive modstykke til det meningsløse industriarbejde søges i privatlivet og i en uproblematiseret »tilbagevenden « til et liv med jorden og naturen.

Hos Herdal møder man så nogle arbejdere, hvis liv er præget af småborgerlig ideologi, et forvredent seksualliv og af den afmagt og selvundertrykkelse, der er en lige så nærliggende konsekvens af undertrykkelsen som modstanden og oprøret. 
6.

Dermed er der givetvis peget på nogle vigtige sider af arbejderbevidstheden. Spørgsmålet er blot, hvor repræsentative de er hver for sig. Og i hvor høj grad der er tale om beskrivelser og fortolkninger, som henter sit indhold fra virkeligheden og ikke fra forfatternes ønskedrømme og fordomme. Der var jo ikke tale om nogen egentlig litterær bevægelse med samme tendens, men kun om et ret lille antal forfattere, som - for socialdemokraternes vedkommende - blev banket op, netop fordi de delte de bomholtske illusioner om kapitalismen og reformismen.

En mere holdbar brug af skønlitteraturen som kilde forudsætter derfor en analyse af en langt større del af periodens litteratur end den, der i mere snæver forstand kan defineres som warbejderlitteratur«. Der vil imidlertid stadigvæk være tale om en type kildemateriale, der er åbent for mange fortolkninger. De litterære analyser må derfor nødvendigvis konfronteres med den socialhistoriske forskning. Det forsøger Bondebjerg da osse. Han har imidlertid ikke haft eller givet sig tid til selv at supplere den mangelfulde forskning på området og resultatet er derfor lovlig postulerende og i hvert fald i et par tilfælde direkte misvisende.

Det gælder for det forste den noget rigide sondring mellem to forskellige familieformer. Det drejer sig om den såkaldte »subproletariske eller svagere arbejderfamilie, hvor den materielle elendighed og sociale usikkerhed, forstærket af krise og langvarig arbejdsløshed og af tildelingen af de dårligst lønnede job, har modvirket en egentlig familiedannelse«. Heroverfor står så »den mere priviligerede og stærke arbejderfamilie, der i stigende omfang er flyttet til de bedre boliger der opstod f.ex. med det kooperative andels-boligbyggeri eller det funktionalistiske rækkehusog karrébyggeri« (Arbejderkulturs. 53 og Prol. off. s. 142).

Her er kildematerialet tilsyneladende udelukkende teoretisk litteratur af psykoanalytisk og socialpsykologisk art. Holder man sig til den konkrete virkelighed er billedet ikke så entydigt. Så vidt vi har kunnet finde ud af, forholder det sig sådan, at nok har disse to familieformer eksisteret, men størstedelen af arbejderfamilierne har udgjort en mellemgruppe.

Pga. arbejdsløsheden og "fagdøden « var mange faglærte nødt til at tage ufaglært arbejde. I det hele taget betød den sæsonpræ- 
gede arbejdsløshed at grænserne mellem faglærte, ufaglærte og arbejdsløse ofte var flydende. Ser man på boligsituationen, så har de arbejdere der flyttede ud i nybyggeriet nok været både stærkere og mere priviligerede end mange af de familier, der valgte at blive boende. Alene den højere husleje - og måske anderledes normer, påklædning og lignende - har krævet en nogenlunde stabil økonomi. Der var imidlertid osse mange familier, der valgte at blive boende $\mathrm{i}$ de gamle arbejderkvarterer af sociale årsager som f.ex. et større sammenhold, fordi de prioriterede boligen lavt, eller fordi de usikre tider ikke opfordrede til at binde sig til en alt for høj husleje. Heraf følger imidlertid langt fra, at denne store gruppe er så svag, at en egentlig familiedannelse ikke har kunnet realiseres.

Et andet eksempel er vurderingen af realismen i Peder Hansen-romanernes bagudvendte naturlængsel. Her mener Bondebjerg, at Peder Hansens skildringer bekræftes af, at der »netop i 20erne og 30erne sker en voldsom ekspansion i kolonihavebevægelsen« (178). Sagen er imidlertid, at denne ekspansion udelukkende fandt sted i form af en udbygning af kolonihavebevægelsens organisatoriske apparat. Det afgørende, når man diskuterer arbejderklassens bevidsthed, må imidlertid være antallet af haver. Og her forholder det sig faktisk sådan, at der i mellemkrigstiden stort set ikke kom flere til end der var i forvejen. Den egentlige vækst fandt sted mellem 1900 og 1915 , hvor tallet steg fra 4000 til 15.000 .

Disse unøjagtigheder rokker ikke ved det centrale: at Bondebjergs litterære analyser helt oplagt peger på nogle sammenhænge, som den kommende socialhistoriske forskning må tage op.

\section{7.}

Derimod er vi mere skeptiske mht. værdien af at bruge en analyse af Socialdemokratiets og DKPs kulturpolitik som genvej til en større forståelse af arbejderbevidstheden (en anden sag er så, at det naturligvis $i$ sig selv er relevant at få en kompetent gennemgang af kulturpolitikken og kulturdiskussionen). Det er for det første temmelig tvivlsomt, om den tidlige Bomholts forestillinger om en selvstændig arbejderkultur som alternativ til den 
borgerlige kultur modsvares af en bevægelse, der rækker meget længere ud end til dele af partiets akademiske medlemmer og de øverste lag i DSU. Den lethed hvormed radikaliteten afvikles $i$ midten af 30erne tyder ikke på den store gennemslagskraft.

For det andet kan vi ikke få øje på nogen parallel mellem kulturidealismens afblomstring og arbejderbevidsthedens udvikling. Hvis den var der, skulle det jo indebære, at arbejderne her $\mathrm{i}$ 30erne blev mere og mere borgerlige i hovederne. Det er faktisk osse, hvad Bondebjerg siger (at der andre steder står noget andet illustrerer kun uklarheden), idet han opererer med udviklingen af set mere borgerligt begreb om opstigningsmuligheder og chancerne for et mere betryggende og velstillet liv « (135 - vi understreger). Allerede Bondebjergs egen forklaring på denne påståede "mere integrerede klassetænkning« viser det uholdbare $\mathrm{i}$ opfattelsen. Den er angiveligt, at arbejderfamilien i 20erne og 30erne havde sbetydeligt flere penge til disposition til de kulturelle og forbrugsmæssige goder, der ligger ud over den daglige fornødenhed end i perioden forud« (136).

Det er rigtigt, at reallønnen steg stærkt i de første år efter 1 . verdenskrig. Baggrunden var en række efter danske forhold ret militante arbejdskampe. Der var altså her ikke tale om en mere, men om en mindre borgerlig arbejderklasse. Derefter falder reallønnen indtil ca. 1927, hvorefter der så er en opadgående tendens de næste 4-5 år - dog kun til et niveau der ligger en smule over det fra begyndelsen af tyverne. Da krisen sætter ind 1932-33 går det brat nedad igen samtidig med at arbejdsløshedstallene stiger voldsomt. Altså: netop i de år hvor Bomholts flyvske tanker vender tilbage til de mere jordnære normalsocialdemokratiske luftlag sker der en drastisk forringelse af arbejdernes levevilkår og fremtidsudsigter. $H v i s$ arbejderklassen bliver mere borgerliggiort i denne periode, må det derfor have andre årsager end materiel fremgang.

Spørgsmålet er da osse, om det ikke forholder sig omvendt: at arbejderklassens bevidsthed hele tiden har været meget lidt revolutionær, men at de på nogle områder (løn og beskæftigelse) negative erfaringer med klassesamarbejdet begynder at afsætte nogle få og små sprækker i den reformistiske bevidsthed. Det er netop i denne periode SD-toppen strammer grebet om de meni- 
ge arbejdere gennem fagbevægelsens underlægning under partiet og gennem en øget centralisering i fagbevægelsen. Samtidig med at oppositionsbekæmpelsen effektiviseres gennem oprettelsen af HIPA. Foranstaltninger som vel ikke ville være nødvendige, hvis arbejderne år for år blev mere og mere tilfredse med det borgerlige samfund og det socialdemokratiske klassesamarbejde.

Når Bondebjerg har rodet sig ud i disse for os at se uholdbare konstruktioner, hænger det sandsynligvis sammen med forståelsen af den socialdemokratiske reformisme. Her knytter Bondebjerg an til teorien om at reformismen oprindeligt var »revolutionær«, men derefter $\mathrm{i}$ forskellige faser bevæger sig hen mod den endelige integration $i$ det borgerlige samfund $i$ midten af 30erne. Hvilket jo svarer meget godt til Bomholts udvikling på kulturområdet. Tilsvarende mener Bondebjerg og Harsløf, at Socialdemokratiets politik i mellemkrigstiden var udtryk for en opgivelse af nogle såkaldte »alternative magtformer«. Det ville vi gerne have haft dokumenteret. Os bekendt har partiet fra begyndelsen entydigt satset på at opnå resultater via et klassesamarbejde i folketinget og mellem fagbevægelsen og arbejdsgiverne.

8.

Afsluttende vil vi gerne understrege, at vores kritikpunkter er ment som et indlæg i diskussionen om den kommende forskning. Vi har grebet fat der hvor de to bøger er svagest, men vil nødigt misforstås: Vi mener helt oplagt, at der er tale om to vigtige udgivelser. Nok er der mangler ved antologien, men i betragtning af, hvad der ellers findes af tilgængeligt materiale burde den få stor udbredelse i uddannelsessystemet. Langt de fleste af de skribenter der er kommet med skriver et klart og forståeligt dansk. Teksterne er derfor velegnede både til at give større indsigt $\mathrm{i}$, hvordan forholdene var i mellemkrigstiden og som udgangspunkt for mere principielle diskussioner om, hvordan vi kan eller bør indrette vores sociale liv. Proletarisk offentlighed 2 henvender sig nok til et noget snævrere publikum, men vil pga. de kulturpolitiske og litterære analyser - være velegnet som supplement og uddybning for lærerne, ligesom den naturligvis er relevant for den del af venstrefløjen, der interesserer sig for at få mere at vide om arbejderklassens historie. 


\section{Note}

\section{Supplerende litteratur:}

Claus Bryld: Det danske socialdemokrati og revisionismen II (1976), diverse artikler i Historievidenskab nr. 13-14 og 17 og i Arbog for arbejderbevagelsens historie 1976 og 1979, Jørgen Bloch-Poulsen/Morten Thing: Danmarks kommunistiske parti 1918-194l (1979), Hans Erik Avlund Frandsen/Jørgen BlochPoulsen/Morten Thing: Planokonomi og folkefront. Om Socialdemokratiet og DKP i mellemkrigstiden (1979), Lone Bentzen, Lisbeth Pedersen, Nielsine Poulsen, Gurli Rasmussen, Vibeke Thorshøj og Margit Thorsvang: Det uendeligt små og det uendeligt store $i$ arbejderklassens hverdagsliv i mellemkrigstiden (kan lånes på Arbejderbevægelsens bibliotek og arkiv og på Roskilde universitetsbibliotek - et af kapitlerne som specielt handler om boligforholdene offentliggores $i$ et kommende nummer af Historievidenskab). 